\title{
Phototrophic biofilms and their potential applications
}

\author{
G. Roeselers • M. C. M. van Loosdrecht • G. Muyzer
}

Received: 23 February 2007 / Revised and Accepted: 19 June 2007 / Published online: 12 August 2007

(C) Springer Science + Business Media B.V. 2007

\begin{abstract}
Phototrophic biofilms occur on surfaces exposed to light in a range of terrestrial and aquatic environments. Oxygenic phototrophs like diatoms, green algae, and cyanobacteria are the major primary producers that generate energy and reduce carbon dioxide, providing the system with organic substrates and oxygen. Photosynthesis fuels processes and conversions in the total biofilm community, including the metabolism of heterotrophic organisms. A matrix of polymeric substances secreted by phototrophs and heterotrophs enhances the attachment of the biofilm community. This review discusses the actual and potential applications of phototrophic biofilms in wastewater treatment, bioremediation, fish-feed production, biohydrogen production, and soil improvement.
\end{abstract}

Keywords Algae $\cdot$ Cyanobacteria $\cdot$ Microbial mats .

Periphyton $\cdot$ Photosynthesis $\cdot$ Bioremediation

\section{Introduction}

Phototrophic biofilms can best be described as surface attached microbial communities driven by light energy with a photosynthesizing component clearly present. Oxygenic phototrophic microorganisms such as benthic diatoms (centric, pennate, unicellular, and filamentous), unicellular and filamentous cyanobacteria, and benthic green algae generate energy and reduce carbon dioxide, providing organic substrates and oxygen.

G. Roeselers • M. C. M. v. Loosdrecht • G. Muyzer $(\square)$ Department of Biotechnology, Delft University of Technology, Julianalaan 67 ,

2628 BC Delft, The Netherlands

e-mail: g.muijzer@tudelft.nl
The photosynthetic activity fuels processes and conversions in the total biofilm community. For example, heterotrophs derive their organic $\mathrm{C}$ and $\mathrm{N}$ requirements from excreted photosynthates and cell lysates, while nutrient regeneration is enhanced by heterotrophs (Bateson and Ward 1988).

The microorganisms produce extracellular polymeric substances (EPS) that hold the biofilm together (Flemming 1993; Wimpenny et al. 2000). Thick laminated multilayered phototrophic biofilms are usually referred to as microbial mats or phototrophic mats (Guerrero et al. 2002; Roeselers et al. 2007a; Stal et al. 1985; Ward et al. 1998). The top layer of microbial mats is typically dominated by oxygenic phototrophs, such as cyanobacteria (Castenholz 2001a) and diatoms, with underlying or intermixed layers of anoxygenic phototrophs, i.e. green and purple sulfur bacteria (GSB and PSB) (Martinez-Alonso et al. 2005) and Chloroflexi like bacteria (Castenholz 2001b; Ruffroberts et al. 1994).

Steep vertical redox and chemical gradients ( microns to millimeters) that establish in phototrophic biofilms and mats enforce these stratifications in the microbial community (Fig. 1).

Light intensity decreases with depth, restricting phototrophic activity to the upper layer of the mat. Oxygenic photosynthesis results in a steep oxygen gradient that restricts most anoxygenic phototrophs and anaerobic chemotrophs to the lower parts of the mat. However, recent studies have also shown examples of anaerobes thriving in the oxic zone of microbial mats (Cypionka 2000; Schaub and Van Gemerden 1994). The utilization of $\mathrm{CO}_{2}$ during photosynthesis results in a $\mathrm{pH}$ gradient (Revsbech et al. 1983).

Phototrophic biofilms and mats are formed on surfaces in a range of terrestrial and aquatic environments (Chan 


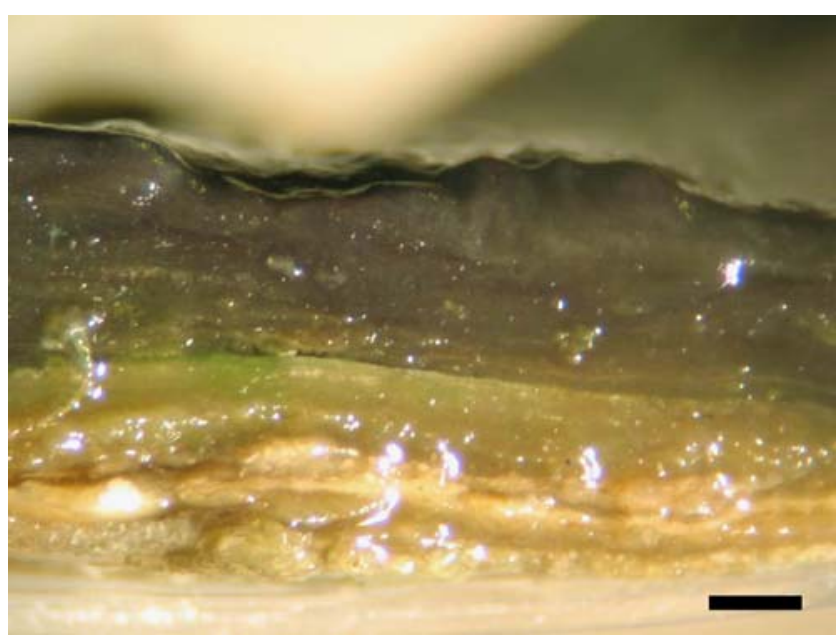

Fig. 1 This cross section reveals the stratified structure of a thick freshwater phototrophic biofilm. The dark top layer consists predominantly of Oscillatoria like cyanobacteria. Scale bar indicates $1 \mathrm{~mm}$

et al. 2003; Ferris et al. 1997; Ortega-Morales et al. 2000). The oldest fossilized phototrophic biofilm or mat-like structures date back approximately 3.5 billion years (Des Marais 1990).

Currently, there is a growing interest in the application of phototrophic biofilms, for instance, in wastewater treatment (Craig et al. 1996; Schumacher and Sekoulov 2002; Vymazal et al. 2001), bioremediation (Blanco et al. 1999; Chaillan et al. 2006; Cohen 2002), aquaculture (Bender and Phillips 2004; Phillips et al. 1994, van Dam et al. 2002), and biohydrogen production (Prince and Kheshgi 2005; Tsygankov et al. 1999). The present review will give a brief introduction to various actual and potential biotechnological applications of phototrophic biofilms.

\section{Wastewater treatment}

The application of oxygenic phototrophs in the treatment of waste streams that are relatively rich in nutrients and low in organic carbon has many advantages. In a heterotrophic biofilm $\mathrm{O}_{2}$ transfer by diffusion is limited to approximately $20 \mathrm{nmol} \mathrm{cm}^{-2} \mathrm{~min}^{-1}$. However, the areal net oxygen production in an active phototrophic biofilm at a light intensity of $1,000 \mu \mathrm{mol}$ photons $\mathrm{m}^{-2} \mathrm{~s}^{-1}$ is approximately a factor of two higher (Epping and Kuhl 2000). Hence, the oxygen that is produced by phototrophs can cover a great part of the oxygen demand of bacterial nitrification and the heterotrophic consumption of organic carbon. In adition, oxygenic phototrophs assimilate nutrients for building biomass with carbon dioxide as carbon source. In contrast to wastewater treatment by bacterial nitrification and denitrification, where a large part of the nitrogen escapes as $\mathrm{N}_{2}$ gas to the atmosphere, the nitrogenous compounds are in this case retained in algal biomass.
Cyanobacteria can assimilate nitrogenous compounds like ammonium, nitrate, nitrite, urea, and amino acids. Diazotrophic cyanobacteria can also assimilate atmospheric nitrogen $\left(\mathrm{N}_{2}\right)$ (Flores and Herrero 2005). However, the reduction of dinitrogen gas to ammonia by nitrogenases is a highly endergonic reaction requiring metabolic energy in the form of ATP. Protection of the sensitive enzyme complex from inactivation by $\mathrm{O}_{2}$, and the replacement of the damaged enzyme add to this high metabolic cost.

The capability of nutrient removal in the absence of organic carbon has often been used for wastewater treatment in algal pond systems (Davis et al. 1990; Garcia et al. 2000). A major disadvantage using suspended algae is the high secondary organic pollution caused by algae biomass in the effluent of the ponds (Racault 1993). Biomass can be removed by filtration, sedimentation with centrifugation, or with decantation, but most of these methods are costly. By using immobilized phototrophic biofilms the problem of separation of suspended algal biomass and water can be avoided and the nitrogenous compounds retained in algal biomass can be harvested and used as fertilizers in agriculture (Schumacher and Sekoulov 2002).

An interesting feature of some cyanobacteria is that they can accumulate inorganic phosphorus and store it internally as polyphosphates (Kromkamp 1987). However, this aspect has hardly been explored in the context of wastewater treatment.

The photosynthetic activity in phototrophic biofilms results in an increasing $\mathrm{pH}$ due to the change of the carbon dioxide equilibrium in water. This increase in $\mathrm{pH}$ causes precipitation of dissolved phosphates, in addition to phosphorus removal by assimilation. This photosynthesis induced $\mathrm{pH}$ increase has also shown potential for the reduction of faecal coliform bacteria in wastewater streams (Schumacher et al. 2003).

European Union regulations have led to more stringent effluent standards for sewage treatment facilities located in ecologically sensitive areas. Phototrophic biofilms can be applied for the additional nutrient removal from secondary effluents of wastewater treatment plants. Nutrient removal in so-called constructed wetlands (Fig. 2), which show potential for small-scale wastewater treatment, depends also to a large extent on the activity of epiphytic phototrophic biofilms growing on reed stems (Larsen and Greenway 2004; Ragusa et al. 2004). Table 1 shows the nitrogen and phosphorus removal rates obtained with several phototrophic biofilm-based wastewater polishing systems.

For process control and system optimization, it is important to define the right operational conditions. Craggs et al. (1996) described several parameters that determine the efficiency of nutrient removal in an experimental phototrophic biofilm system. An important parameter is the 


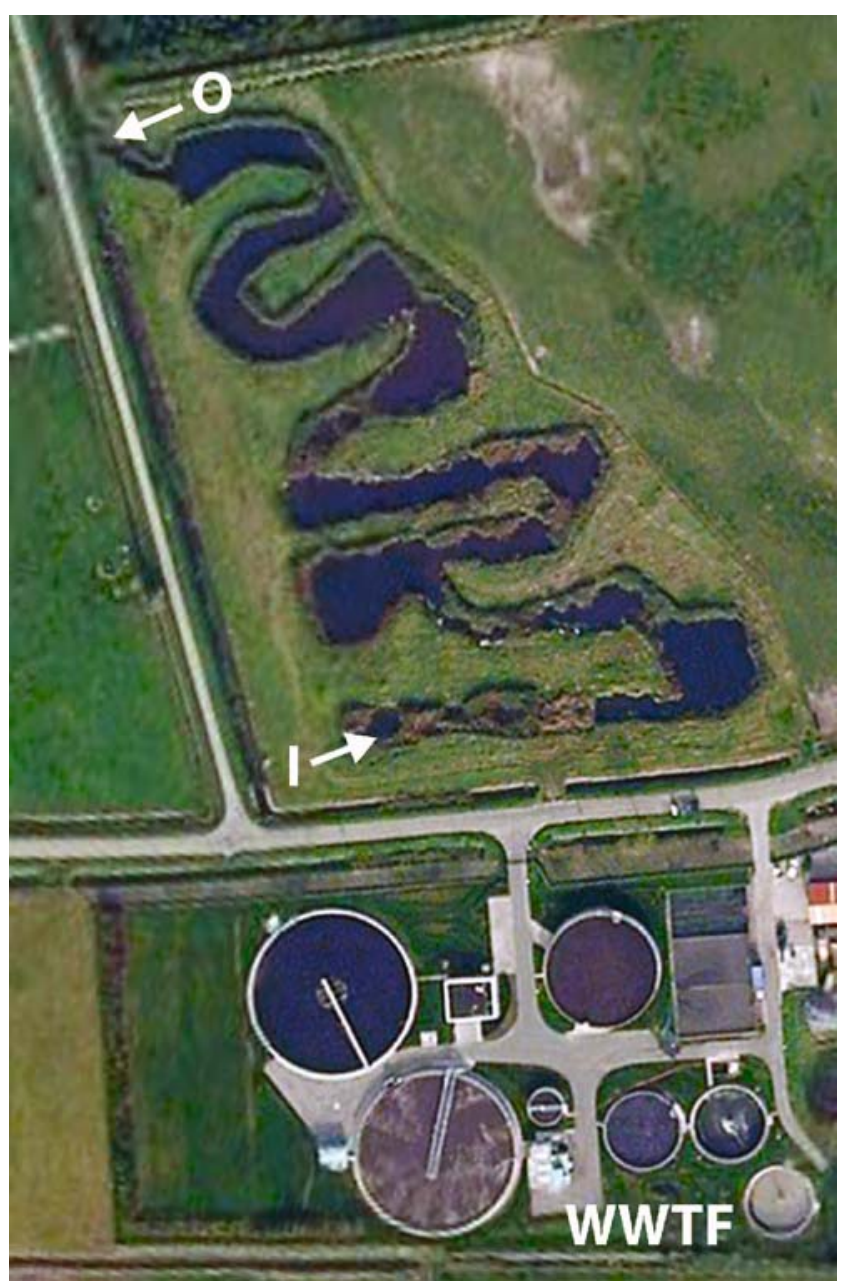

Fig. 2 Discharge of the municipal wastewater treatment facility (WWTF) of Sint Maartensdijk (the Netherlands) is polished in a constructed wetland system $(\mathrm{I}=$ inlet, $\mathrm{O}=$ outlet). Nitrate is primarily assimilated by epiphytic phototrophic biofilms growing on reed stems

applied flow velocity. At higher flow velocities there is a trade-off between reduced colonization and shear stress versus increased metabolism in the established biofilms by reduced boundary layers and increased water mixing.

Two parameters that are interconnected are water depth and light intensity. Algal production generally declines with water depth because increased water depths result in reduced light penetration (Craggs et al. 1996; Havens et al. 1996). However, in shallow water with a limited flow-velocity, the reduced load can lead to conditions were the biofilm becomes nutrient limited instead of light limited. Hence, optimal water depths will also depend on nutrient loads and local or seasonal light conditions.

\section{Removal of heavy metals}

Biosorption consists of several mechanisms, mainly ion exchange, chelation, adsorption, and diffusion through cell walls. These "passive" mechanisms can take place at the cellular level and at the microbial community level. The active mode of metal uptake and concentration is called bioaccumulation. This process is dependent on the cellular metabolism.

Many oxygenic phototrophic microorganisms have the capability to sorb or accumulate metals in one way or another, and there is considerable potential for the application of algal biofilms in the detoxification of wastewaters polluted with heavy metals (Bender et al. 1994; Mehta and Gaur 2005). Extracellular polysaccharides that are negatively charged at elevated $\mathrm{pH}$ levels generated by oxygenic photosynthesis may account for the metal-binding properties of phototrophic biofilms (Bender et al. 1994; Bhaskar and Bhosle 2006; Liu et al. 2001; Wang et al. 1998). Parker et al. (2000) showed that mucilage sheaths isolated from the cyanobacteria Microcystis aeruginosa and Aphanothece halophytica exhibit strong affinity for heavy metal ions such as copper, lead, and zinc. In addition to biosorption and bioaccumulation, the elevated $\mathrm{pH}$ inside photosyntetically active biofilms may favor removal of metals by precipitation (Liehr et al. 1994).

Major advantages of metal removal by biosorption include, low cost, and high efficiency of heavy metal removal from diluted solutions. However, in order not to simply displace heavy metal pollution, methods will have to be developed to extract heavy metals easily from biomass (Kratochvil and Volesky 1998).

Water hardness is a crucial factor that influences metal uptake efficiency because cations such as $\mathrm{Ca}^{2+}$ and $\mathrm{Mg}^{2+}$ compete with trace metals for binding sites on cell membranes and extracellular polysaccharides (Fortin et al.

Table 1 Nitrogen and phosphorus removal rates obtained with different phototrophic biofilm based wastewater treatment systems

\begin{tabular}{llll}
\hline System & $\begin{array}{l}\text { N-removal } \\
\text { rate }^{\mathrm{a}}\end{array}$ & $\begin{array}{l}\text { P-removal } \\
\text { rate }^{\mathrm{b}}\end{array}$ & Reference \\
\hline $\begin{array}{c}\text { Algal turf } \\
\text { scrubber (ATS) }\end{array}$ & 1,110 & 730 & $\begin{array}{c}\text { Craggs et al. } \\
1996\end{array}$ \\
$\begin{array}{l}\text { Periphyton-fish } \\
\text { system }\end{array}$ & 108 & 27 & $\begin{array}{c}\text { Rectenwald } \\
\text { and Drenner }\end{array}$ \\
$\begin{array}{l}\text { mesocosm } \\
\begin{array}{l}\text { Secondary } \\
\text { effluent } \\
\text { clarifier }\end{array}\end{array}$ & 1,900 & 160 & $\begin{array}{c}2000 \\
\text { Davis et al. } \\
1990\end{array}$ \\
$\begin{array}{l}\text { ATS fed with } \\
\begin{array}{l}\text { 1\% dairy } \\
\text { manure }\end{array}\end{array}$ & 720 & 330 & $\begin{array}{c}\text { Pizarro et al. } \\
2002\end{array}$ \\
$\begin{array}{l}\text { Phototrophic } \\
\text { biofilms in } \\
\text { natural streams }\end{array}$ & 648 & & $\begin{array}{c}\text { Davis and } \\
\text { Minshall }\end{array}$ \\
\hline
\end{tabular}

${ }^{\mathrm{a}}$ Average phosphorus removal rates $\left(\mathrm{mg} \mathrm{P} \mathrm{m}^{-2}\right.$ day $^{-1}$ )

${ }^{\mathrm{b}}$ Average nitrogen removal rates $\left(\mathrm{mg} \mathrm{N} \mathrm{m}^{-2}\right.$ day $\left.^{-1}\right)$ 
2007). Meylan et al. (2003) showed that different concentrations of dissolved manganese affected the intracellular accumulation of zinc and copper by phototrophic biofilms. In addition to cation concentrations, metal uptake is affected by light intensity, $\mathrm{pH}$, biofilm density, the presence of metal binding humic substances, and the tolerance of individual algal species to specific heavy metals (Fortin et al. 2007; Vymazal 1984).

\section{Oil degradation}

The volumes of petroleum-based products transported across the world are enormous and the risk of oil spillage is significant. The volume of spills usually exceeds the inherent remediation capacity for any given environment, resulting in a significant ecological impact (Cohen 2002). It has been suggested that microbial mats can play a role in the biodegradation of oil. In the years after the massive oil spills during the first Gulf war of 1991, it was observed that dense mats of cyanobacteria formed on contaminated beaches (Sorkhoh et al. 1992). It has been shown that, in particular, Oscillatoria spp. are able to cope with heavy oil pollution (Abed et al. 2006; Cohen 2002; van Bleijswijk and Muyzer 2004).

Although there is no direct evidence that cyanobacteria are directly involved in the degradation of petroleum products, they probably facilitate degradation by sulfatereducing bacteria (Edwards et al. 1992) and aerobic heterotrophs (Benthien et al. 2004; Cohen 2002; Sorkhoh et al. 1995). Previous studies have shown that the addition of nitrogen supplements enhances microbial assimilation of carbon from oil (Coffin et al. 1997). Cyanobacterial $\mathrm{N}_{2}$ fixation could provide sufficient nitrogen compounds for heterotrophic oil degradation. Free radicals formed during oxygenic photosynthesis could indirectly enhance photochemical oil degradation (Nicodem et al. 1997).

Microcosm studies examining the initial response of phototrophic biofilms exposed to petrochemical compounds revealed signs of acute toxicity (Nayar et al. 2004). Phototrophic biofilms are ubiquitous and dominant primary producers forming the base of aquatic food webs. Therefore, it has been suggested that phototrophic biofilms are applicable as sensitive bioindicators of petrochemical pollution and for ecotoxicology tests (Nayar et al. 2004).

\section{Agriculture}

When phototrophic biofilms are used for polishing of nitrate or ammonium-containing wastewater streams, the nitrogen that is retained in biomass can be used as a fertilizer in agriculture. Biomass applied in the remediation of waste streams containing hazardous metals or recalcitrant organic pollutants is not directly applicable as a fertilizer.

Cyanobacteria can also be applied for in situ soil fertilization via $\mathrm{N}_{2}$ fixation. Much work has been done on the fertilization of rice paddy fields with nitrogen fixing cyanobacteria (Ariosa et al. 2004; Habte and Alexander 1980; Lem and Glick 1985).

In addition, EPS produced by algae and cyanobacteria can improve the soil water-holding capacity and prevent erosion (Barclay and Lewin 1985; Rao and Burns 1990). Mazor et al. (1996) showed that addition of $0.5 \mathrm{mg}$ of Microcoleus sp. EPS per gram of sand retained approximately $30 \%$ of the water-holding capacity of the sand after $24 \mathrm{~h}$ of desiccation at $55^{\circ} \mathrm{C}$, while sand samples without EPS dried out completely.

Elevated soil salinity, which is increasing worldwide, has a major impact on soil quality and agricultural production. In many coastal areas, salinity is an inherent situation, but inefficient water management, i.e. excess recharging of groundwater and accumulation through concentration often leads to secondary salinization of farmlands. In the early 1950s a biological approach to the problem of saline soils using cyanobacteria was proposed (Singh 1950). It has been shown that inoculation of soil surfaces with a suspension of halotolerant cyanobacteria leads to a salinity reduction (Apte and Thomas 1997; Kaushik and Venkataraman 1982). This amelioration of soil salinity is probably caused by a temporal entrapment of $\mathrm{Na}^{+}$ions in cyanobacterial EPS sheaths, resulting in a restricted $\mathrm{Na}+$ influx in the plant roots (Ashraf et al. 2006). Permanent removal of $\mathrm{Na}^{+}$from the soil may not be possible, because $\mathrm{Na}^{+}$is released back into the soil subsequent to the death and decay of the cyanobacteria.

\section{Aquaculture}

Effluent discharges of intensive fish production systems may cause significant nutrient pollution. Fish farmers have a stake in regulating nutrient pollution, because poor water quality can reduce aquaculture productivity. On a small scale phototrophic biofilm based systems can be used to reduce ammonia and nitrate concentrations in aquaculture effluents (Bender and Phillips 2004).

In fish aquacultures, commercial feeds, consisting mostly of fishmeal and oil, may account for more than $50 \%$ of the total production costs (Elsayed and Teshima 1991). Only about $15-30 \%$ of the nutrient input in feeddriven pond systems is converted into harvestable products (Gross et al. 2000). Therefore, there is a growing interest for substitution of commercial feeds with alternative protein sources. The cost savings and the reduction of ecological impact by using phototrophic biofilms for fish feed 
production and the possible simultaneous effluent treatment may be significant (Elsayed and Teshima 1991; Naylor et al. 2000; Phillips et al. 1994).

Tilapia (Oreochromis niloticus) can consume microalgae as a major, even exclusive, source of its feed requirements. Due to their omnivorous diet and rapid growth, species of tilapia are highly suitable for aquaculturing in fertized pond systems. In fertilized ponds, organic and inorganic fertilizers are used to increase productivity. Nutrients are incorporated into algal biomass and, through a complex food web, ultimately incorporated into fish biomass.

Azim et al. (2003) showed that by adding substrate for biofilm adherence to fertilized aquaculture ponds, the conversion of nutrients into harvestable products could be optimized. Tilapia growth was significantly higher and nitrogen retention doubled in substrate ponds compared with control ponds. The potential of fish production based on phototrophic biofilms was reviewed in detail by van Dam et al. (2002).

Cyanobacteria that produce toxic secondary metabolites may cause problems to the expanding aquaculture industry. For example, Aphanizomenon and Mycrocystis-like species produce so-called microcystins that can accumulate in fish tissue used for human consumption (Magalhaes et al. 2001; Wiegand and Pflugmacher 2005). The occurrence of toxins has often been related to rapid planctonic cyanobacterial biomass development during algal blooms but this link is much less common in benthic assemblages (Blaha et al. 2004).

\section{Biohydrogen}

Hydrogen is a clean alternative to fossil fuels as its combustion generates only water as a byproduct. Biological production of hydrogen could provide a renewable source of energy. Cyanobacteria are highly promising microorganisms for biological photohydrogen production. Two cyanobacterial enzymes are capable of hydrogen production. The bidirectional hydrogenase complex can either produce or oxidize $\mathrm{H}_{2}$ in the presence of suitable electron donor or acceptor. The physiological role of bidirectional hydrogenases is still unclear and the enzyme is absent in a significant number of strains.

Hydrogen evolution is also catalyzed by nitrogenases (Mancinelli 1996; Tamagnini et al. 2002; Zehr and Turner 2001). The nitrogenase machinery releases at least one mol $\mathrm{H}_{2}$ per mol $\mathrm{N}_{2}$ reduced to ammonia, which represents a significant loss of energy. However, most diazotrophic cyanobacteria possess an enzyme called uptake hydrogenase that serves to recycle some of the electrons lost in the form of $\mathrm{H}_{2}$. Several studies with bioreactors have demonstrated the feasibility of cyanobacterial biohydrogen production
(Lindberg et al. 2004; Schutz et al. 2004; Tsygankov et al. 1999). As mentioned, $\mathrm{N}_{2}$ reduction has a high ATP requirement and this reduces the potential conversion of solar energy considerably. An advantageous aspect of this is that ATP hydrolysis provides a relatively strong thermodynamic driving force pushing hydrogen evolution, which is not true for bidirectional hydrogenases (Prince and Kheshgi 2005). This allows the generation of a higher partial $\mathrm{H}_{2}$ pressure in potential bioreactors.

Ideally, hydrogen producing cyanobacteria should invest a minimal amount of ATP in growth, have a high metabolism, and should be restricted in place. Attached cyanobacterial assemblages are of great interest because they meet up to these requirements. The efficiency of hydrogen production could be increased by constructing defined biofilm assemblages containing a range of desired cyanobacterial species or genetically modified strains with a reduced uptake hydrogenase activity (Lindberg et al. 2004; Tsygankov et al. 1999). In order to select an "optimal genetic background" for the construction of genetically engineered cyanobacteria, future studies should focus on the natural molecular variation of strains that have the potential to produce hydrogen. Currently, this technology is in its infancy and as yet not ready for commercial adaptation and exploitation.

\section{Anoxygenic phototrophs and sulfide removal}

Sulfide-containing waste streams are usually treated in reactors by chemotrophic sulfide-oxidizing microorganisms using either oxygen or nitrate as the ultimate electron acceptor. In many bioreactors, sulfide is transformed into sulfate by aerobic sulfur-oxidizing bacteria, such as different species of the genus Thiobacillus.

A disadvantage of using aerobic sulfur-oxidizing bacteria is that sulfide removal cannot be combined with sewage treatment by anaerobic digestion. Sulfide oxidation has to take place in a separate reactor in order to avoid exposure of strictly anaerobic methanogens to inhibitory levels of oxygen. Hence, anaerobic oxidation by phototrophic sulfur bacteria (Chloroflexi, GSB, and PSB) has been proposed as an alternative method for sulfide removal (Kim et al. 1990).

There is a particular interest in reactors using immobilized biofilms because suspended microbial biomass is easily washed out from the system whenever growth rates are disturbed. Several laboratory scale studies with monospecies and multispecies biofilms of anoxygenic phototrophic bacteria showed promising results (Ferrera et al. 2004; Kobayashi et al. 1983; Syed and Henshaw 2003).

Only very few processes based on substratum-irradiated biofilms have been employed for large scale treatment of 
sulfide-containing waste streams (Hurse and Keller 2004; Jensen and Webb 1995).

\section{Conclusions and future perspectives}

The field of microbiology has come to accept the universality of biofilms. Researchers in the fields of clinical, food and water, and environmental microbiology have begun to investigate microbiological processes from a biofilm perspective. There are multiple examples of genotypic and physiological differences between microorganisms growing planktonic or in biofilms. Until recently, applied phycological studies have focused mainly on the planktonic mode of life.

In this review we have discussed potential and actual applications of phototrophic biofilm biotechnology in the development of clean energy systems, wastewater treatment, bioremediation, fish feed production, and soil fertilization.

In the context of potential applications, the most important features of these biofilm systems are versatility and adaptability, i.e. they have a broad spectrum of capabilities. This makes it possible to link different end uses within the same process; for example, nitrate and phosphate removal combined with production of fish feeds (Bender and Phillips 2004).

The complexity in terms of species richness is an important aspect determining the metabolic biodiversity and adaptability of phototrophic biofilms (Boles et al. 2004; Girvan et al. 2005). In addition, applications of pure culture or defined community biofilms seem less attractive due to the high costs associated with control of the culture performance and equipment sterilization and isolation to prevent contaminations. Hence, the focus of application development should be on the use of open mixed culture systems. Therefore, a clear understanding of the ecology of phototropic biofilm communities is essential in order to optimize their cultivation for specific biotechnological applications.

Depending on the application it can be essential to select phototropic biofilms containing specific species and strains, e.g. strains with a high polyunsaturated fatty acid content, strains that do or do not secrete harmful secondary metabolites, strains producing EPS with high metal sorption capacities, or strains with a high tolerance for petroleumbased compounds.

The efficiency and reliability of phototrophic biofilm applications depend to a great extent on the option to select and maintain desired community compositions. Future studies should focus on successional changes during biofilm development (Chan et al. 2003; Roeselers et al. 2007b), susceptibility to viral and grazing pressure (Simek and Chrzanowski 1992; Thingstad 2000), the mechanisms that determine the structural and functional responses to abrupt perpetuations, and seasonal fluctuations on community composition and productivity (Kaufman 1982).

Molecular ecological techniques that allow detailed in situ characterization of community compositions and activities provide an important tool for future research. Nonculture-based molecular methods such as DGGE, clone library analysis, quantitative PCR, and stable isotope probing can be used to obtain the phylogeny, relative abundance, and genetic activity of individual members of a biofilm community (Omoregie et al. 2004; Roeselers et al. 2006; Steunou et al. 2006). In particular, functional genomics approaches will offer important clues about phototrophic biofilm biology.

An important consideration for applications based on phototrophic activity in general is that they require much surface area. These systems are primarily fueled by light, which differs from all other resources because it cannot be mixed. The unidirectional nature of photons requires that biofilms are cultivated on surfaces exposed to direct solar radiation. Therefore, high land prices could be a major hurdle for applications in, for instance, the treatment of municipal wastewater in densely populated areas. Combining different end uses within processes could compensate for the cost of these relatively large footprints. Phototrophic biofilms would also be suitable for the development of inexpensive treatment methods for developing countries, where land values are relatively low and where the bulk of domestic and industrial wastewater is still discharged without any treatment.

Acknowledgements This work was supported by the project PHOBIA (QLK3-CT-2002-01938) funded under European Union Framework V. We thank Dr. Henk Jonkers and two anonymous reviewers for their thoughtful comments on this manuscript.

\section{References}

Abed RM, Al-Thukair A, de Beer D (2006) Bacterial diversity of a cyanobacterial mat degrading petroleum compounds at elevated salinities and temperatures. FEMS Microbiol Ecol 57:290-301

Apte SK, Thomas J (1997) Possible amelioration of coastal soil salinity using halotolerant nitrogen-fixing cyanobacteria. Plant Soil 189:205-211

Ariosa Y, Quesada A, Aburto J, Carrasco D, Carreres R, Leganes F, Fernandez Valiente E (2004) Epiphytic cyanobacteria on Chara vulgaris are the main contributors to $\mathrm{N}(2)$ fixation in rice fields. Appl Environ Microbiol 70:5391-5397

Ashraf M, Hasnain S, Berge O (2006) Effect of exo-polysaccharides producing bacterial inoculation on growth of roots of wheat (Triticum aestivum) plants grown in a salt-affected soil. IJEST 3:43-51

Azim ME, Verdegem MCJ, Singh M, van Dam AA, Beveridge MCM (2003) The effects of periphyton substrate and fish density on 
water quality, phytoplankton, periphyton and fish growth. Aquac Res 34:685-695

Barclay WR, Lewin RA (1985) Microalgal polysaccharide production for the conditioning of agricultural soils. Plant Soil 88:159-169

Bateson MM, Ward DM (1988) Photoexcretion and fate of glycolate in a hot spring cyanobacterial mat. Appl Environ Microbiol 54:1738-1743

Bender J, Rodriguez-Eaton S, Ekanemesang UM, Phillips P (1994) Characterization of metal-binding bioflocculants produced by the cyanobacterial component of mixed microbial mats. Appl Environ Microbiol 60:2311-2315

Bender J, Phillips P (2004) Microbial mats for multiple applications in aquaculture and bioremediation. Bioresour Technol 94:229-238

Benthien M, Wieland A, García de Oteyza T, Grimalt JO, Kühl M (2004) Oil-contamination effects on a hypersaline microbial mat community (Camargue, France) as studied with microsensors and geochemical analysis. OPHELIA 58:135-150

Bhaskar PV, Bhosle NB (2006) Bacterial extracellular polymeric substance (EPS): a carrier of heavy metals in the marine foodchain. Environ Int 32:191-198

Blaha L, Sabater S, Babica P, Vilalta E, Marsalek B (2004) Geosmin occurrence in riverine cyanobacterial mats: is it causing a significant health hazard? Water Sci Technol 49:307-312

Blanco A, Sanz B, Llama MJ, Serra JL (1999) Biosorption of heavy metals to immobilised Phormidium laminosum biomass. J Biotechnol 69:227-240

Boles BR, Thoendel M, Singh PK (2004) Self-generated diversity produces "insurance effects" in biofilm communities. Proc Natl Acad Sci USA 101:16630-16635

Castenholz RW (2001a) Phylum BX. Cyanobacteria. Oxygenic photosynthetic bacteria. In: Boone DR, Castenholz RW, Garrity GM (eds) Bergey's manual of systematic bacteriology. Springer, New York, pp 474-487

Castenholz RW (2001b) Class I: Chloroflexi. In: Boone DR, Castenholz RW, Garrity GM (eds) Bergey's manual of systematic bacteriology. Springer, New York, pp 427

Chaillan F, Gugger M, Saliot A, Coute A, Oudot J (2006) Role of cyanobacteria in the biodegradation of crude oil by a tropical cyanobacterial mat. Chemosphere 62:1574-1582

Chan BK, Chan WK, Walker G (2003) Patterns of biofilm succession on a sheltered rocky shore in Hong Kong. Biofouling 19:371380

Coffin RB, Cifuentes LA, Pritchard PH (1997) Assimilation of oilderived carbon and remedial nitrogen applications by intertidal food chains on a contaminated beach in Prince William Sound, Alaska. Mar Environ Res 44:27-39

Cohen Y (2002) Bioremediation of oil by marine microbial mats. Int Microbiol 5:189-193

Craggs RJ, Adey WH, Jessup BK, Oswald WJ (1996) A controlled stream mesocosm for tertiary treatment of sewage. Ecol Eng 6:149-169

Craig RJ, Adey WH, Jenson KR, St. John MS, Green FB, Oswald J (1996) Phosphorus removal from wastewater using an algal turf scrubber. Water Sci Technol 33:191-198

Cypionka H (2000) Oxygen respiration by desulfovibrio species. Annu Rev Microbiol 54:827-848

Davis JC, Minshall GW (1999) Nitrogen and phosphorus uptake in two Idaho (USA) headwater wilderness streams. Oecologia 119:247-255

Davis LS, Hoffmann JP, Cook PW (1990) Production and nutrient accumulation by periphyton in a waste-water treatment facility. J Phycol 26:617-623

Des Marais DJ (1990) Microbial mats and the early evolution of life. Trends Ecol Evol 5:140-144

Edwards EA, Wills LE, Reinhard M, Grbic-Galic D (1992) Anaerobic degradation of toluene and xylene by aquifer microorganisms under sulfate-reducing conditions. Appl Environ Microbiol 58:794-800

Elsayed AFM, Teshima SI (1991) Tilapia nutrition in aquaculture. Rev Aquat Sci 5:247-265

Epping E, Kuhl M (2000) The responses of photosynthesis and oxygen consumption to short-term changes in temperature and irradiance in a cyanobacterial mat (Ebro Delta, Spain). Environ Microbiol 2:465-474

Ferrera I, Sanchez O, Mas J (2004) A new non-aerated illuminated packed-column reactor for the development of sulfide-oxidizing biofilms. Appl Microbiol Biotechnol 64:659-664

Ferris MJ, Nold SC, Revsbech NP, Ward DM (1997) Population structure and physiological changes within a hot spring microbial mat community following disturbance. Appl Environ Microbiol 63:1367-1374

Flemming HC (1993) Biofilms and environmental-protection. Water Sci Technol 27:1-10

Flores E, Herrero A (2005) Nitrogen assimilation and nitrogen control in cyanobacteria. Biochem Soc Trans 33:164-167

Fortin C, Denison FH, Garnier-Laplace J (2007) Metal-phytoplankton interactions: modeling the effect of competing ions $\left(\mathrm{H}^{+}, \mathrm{Ca}_{2}{ }^{+}\right.$, and $\mathrm{Mg}_{2}{ }^{+}$) on uranium uptake. Environ Toxicol Chem 26:242248

Garcia J, Mujeriego R, Hernandez-Marine M (2000) High rate algal pond operating strategies for urban wastewater nitrogen removal. J Appl Phycol 12:331-339

Girvan MS, Campbell CD, Killham K, Prosser JI, Glover LA (2005) Bacterial diversity promotes community stability and functional resilience after perturbation. Environ Microbiol 7:301-313

Gross A, Boyd CE, Wood CW (2000) Nitrogen transformations and balance in channel catfish ponds. Aquac Eng 24:1-14

Guerrero R, Piqueras M, Berlanga M (2002) Microbial mats and the search for minimal ecosystems. Int Microbiol 5:177-188

Habte M, Alexander M (1980) Nitrogen fixation by photosynthetic bacteria in lowland rice culture. Appl Environ Microbiol 39:342347

Havens KE, East TL, Meeker RH, Davis WP, Steinman AD (1996) Phytoplankton and periphyton responses to in situ experimental nutrient enrichment in a shallow subtropical lake. J Plankton Res 18:551-566

Hurse TJ, Keller J (2004) Reconsidering the use of photosynthetic bacteria for removal of sulfide from wastewater. Biotechnol Bioeng 85:47-55

Jensen AB, Webb C (1995) Treatment of H2S-containing gases - a review of microbiological alternatives. Enzyme Microb Technol 17:2-10

Kaushik BD, Venkataraman GS (1982) Reclamative capacity of bluegreen algae in saline and sodic soils. In: Proceedings of the National Symposium on Biological Nitrogen Fixation, Department of Atomic Energy, Bombay, pp 378-389

Kaufman LH (1982) Stream aufwuchs accumulation: disturbance frequency and stress resistance and resilience. Oecologia 52:57-63

Kim BW, Kim IK, Chang HN (1990) Bioconversion of hydrogen sulfide by free and immobilized cells of Chlorobium thiosulfatophilum. Biotechnol Lett 12:381-386

Kobayashi HA, Stenstrom M, Mah RA (1983) Use of photosynthetic bacteria for hydrogen-sulfide removal from anaerobic waste treatment effluent. Water Res 17:579-587

Kratochvil D, Volesky B (1998) Biosorption of $\mathrm{Cu}$ from ferruginous wastewater by algal biomass. Water Res 32:2760-2768

Kromkamp J (1987) Formation and functional-significance of storage products in cyanobacteria. N Z J Mar Freshwater Res 21:457465

Larsen E, Greenway M (2004) Quantification of biofilms in a subsurface flow wetland and their role in nutrient removal. Water Sci Technol 49:115-122 
Lem NW, Glick BR (1985) Biotechnological uses of cyanobacteria. Biotechnol Adv 3:195-208

Liehr SK, Chen HJ, Lin SH (1994) Metals removal by algal biofilms. Water Sci Technol 30:59-68

Lindberg P, Lindblad P, Cournac L (2004) Gas exchange in the filamentous cyanobacterium Nostoc punctiforme strain ATCC 29133 and its hydrogenase-deficient mutant strain NHM5. Appl Environ Microbiol 70:2137-2145

Liu Y, Lam MC, Fang HH (2001) Adsorption of heavy metals by EPS of activated sludge. Water Sci Technol 43:59-66

Magalhaes VF, Soares RM, Azevedo SM (2001) Microcystin contamination in fish from the Jacarepagua Lagoon (Rio de Janeiro, Brazil): ecological implication and human health risk. Toxicon 39:1077-1085

Mancinelli RL (1996) The nature of nitrogen: an overview. Life Support Biosph Sci 3:17-24

Martinez-Alonso M, Van Bleijswijk J, Gaju N, Muyzer G (2005) Diversity of anoxygenic phototrophic sulfur bacteria in the microbial mats of the Ebro Delta: a combined morphological and molecular approach. FEMS Microbiol Ecol 52:339-350

Mazor G, Kidron GJ, Vonshak A, Abeliovich A (1996) The role of cyanobacterial exopolysaccharides in structuring desert microbial crusts. FEMS Microb Ecol 21:121-130

Mehta SK, Gaur JP (2005) Use of algae for removing heavy metal ions from wastewater: progress and prospects. Crit Rev Biotechnol 25:113-152

Meylan S, Behra R, Sigg L (2003) Accumulation of copper and zinc in periphyton in response to dynamic variations of metal speciation in freshwater. Environ Sci Technol 37:5204-5212

Naylor RL, Goldburg RJ, Primavera JH et al (2000) Effect of aquaculture on world fish supplies. Nature 405:1017-1024

Nayar S, Goh BPL, Chou LM (2004) The impact of petroleum hydrocarbons (diesel) on periphyton in an impacted tropical estuary based on in situ microcosms. J Exp Mar Bio Ecol 302:213-232

Nicodem DE, Fernandes MCZ, Guedes CLB, Correa RJ (1997) Photochemical processes and the environmental impact of petroleum spills. Biogeochemistry 39:121-138

Omoregie EO, Crumbliss LL, Bebout BM, Zehr JP (2004) Determination of nitrogen-fixing phylotypes in Lyngbya sp. and Microcoleus chthonoplastes cyanobacterial mats from Guerrero Negro, Baja California, Mexico. Appl Environ Microbiol 70:2119 2128

Ortega-Morales O, Guezennec J, Hernández-Duque G, Gaylarde CC, Gaylarde PM (2000) Phototrophic biofilms on ancient Mayan buildings in Yucatan, Mexico. Curr Microbiol 40:81-85

Parker DL, Mihalick JE, Plude JL, Plude MJ, Clark TP, Egan L, Flom JJ, Rai LC, Kumar HD (2000) Sorption of metals by extracellular polymers from the cyanobacterium Microcystis aeruginosa $\mathrm{f}$. flos-aquae strain C3-40. J Appl Phycol 12:219-224

Phillips P, Russell A, Bender J, Muñoz R (1994) Management plan for utilization of a floating microbial mat with its associated detrital gelatinous layer as a complete tilapia Oreochromis niloticus feed system. Bioresour Technol 47:239-245

Pizarro C, Kebede-Westhead E, Mulbry W (2002) Nitrogen and phosphorus removal rates using small algal turfs grown withdairy manure. J Appl Phycol 14:469-473

Prince RC, Kheshgi HS (2005) The photobiological production of hydrogen: potential efficiency and effectiveness as a renewable fuel. Crit Rev Microbiol 31:19-31

Racault Y (1993) Pond malfunction: case study of three plants in the south-west of France. Water Sci Technol 28:183-192

Ragusa SR, McNevin D, Qasem S, Mitchell C (2004) Indicators of biofilm development and activity in constructed wetlands microcosms. Water Res 38:2865-2873
Rao DLN, Burns RG (1990) The effect of surface growth of bluegreen-algae and bryophytes on some microbiological, biochemical, and physical soil properties. Biol Fertil Soils 9:239-244

Rectenwald LL, Drenner RW (2000) Nutrient removal from wastewater effluent using an ecological water treatment system. Environ Sci Technol 34:522-526

Revsbech NP, Jorgensen BB, Blackburn TH, Cohen Y (1983) Microelectrode studies of the photosynthesis and $\mathrm{O}_{2}, \mathrm{H}_{2} \mathrm{~S}$, and $\mathrm{pH}$ profiles of a microbial mat. Limnol Oceanogr 28:1062-1074

Roeselers G, Zippel B, Staal M, van Loosdrecht M, Muyzer G (2006) On the reproducibility of microcosm experiments - different community composition in parallel phototrophic biofilm microcosms. FEMS Microbiol Ecol 58:169-178

Roeselers G, Norris T, Castenholz R, Rysgaard S, Glud R, Kuhl M, Muyzer G (2007a) Diversity of phototrophic bacteria in microbial mats from Arctic hot springs (Greenland). Environ Microbiol 9:26-38

Roeselers G, van Loosdrecht MCM, Muyzer G (2007b) Heterotrophic pioneers facilitate phototrophic biofilm development. Microb Ecol. DOI 10.1007/s00248-007-9238-x

Ruffroberts AL, Kuenen JG, Ward DM (1994) Distribution of cultivated and uncultivated cyanobacteria and Chloroflexus-Like bacteria in hot-spring microbial mats. Appl Environ Microbiol 60:697-704

Schaub BEM, Van Gemerden H (1994) Simultaneous phototrophic and chemotropic growth in the purple sulfur bacterium thiocapsaRoseopersicina M1. FEMS Microbiol Ecol 13:185-195

Schumacher G, Sekoulov I (2002) Polishing of secondary effluent by an algal biofilm process. Water Sci Technol 46:83-90

Schumacher G, Blume T, Sekoulov I (2003) Bacteria reduction and nutrient removal in small wastewater treatment plants by an algal biofilm. Water Sci Technol 47:195-202

Schutz K, Happe T, Troshina O, Lindblad P, Leitao E, Oliveira P, Tamagnini P (2004) Cyanobacterial $\mathrm{H}(2)$ production - a comparative analysis. Planta 218:350-359

Simek K, Chrzanowski TH (1992) Direct and indirect evidence of size-selective grazing on pelagic bacteria by fresh-water nanoflagellates. Appl Environ Microbiol 58:3715-3720

Singh RN (1950) Reclamation of 'usar' lands in India through bluegreen algæ. Nature 165:325-326

Sorkhoh N, Al-Hasan R, Radwan S, Höpner T (1992) Self-cleaning of the Gulf. Nature 359:109

Sorkhoh NA, al-Hasan RH, Khanafer M, Radwan SS (1995) Establishment of oil-degrading bacteria associated with cyanobacteria in oil-polluted soil. J Appl Bacteriol 78:194-199

Stal LJ, Van Gemerden H, Krumbein WE (1985) Structure and development of a benthic marine microbial mat. FEMS Microbiol Ecol 31:111-125

Steunou AS, Bhaya D, Bateson MM, Melendrez MC, Ward DM, Brecht E, Peters JW, Kuhl M, Grossman AR (2006) In situ analysis of nitrogen fixation and metabolic switching in unicellular thermophilic cyanobacteria inhabiting hot spring microbial mats. Proc Natl Acad Sci USA 103:2398-2403

Syed MA, Henshaw PF (2003) Effect of tube size on performance of a fixed-film tubular bioreactor for conversion of hydrogen sulfide to elemental sulfur. Water Res 37:1932-1938

Tamagnini P, Axelsson R, Lindberg P, Oxelfelt F, Wunschiers R, Lindblad P (2002) Hydrogenases and hydrogen metabolism of cyanobacteria. Microbiol Mol Biol Rev 66:1-20

Thingstad TF (2000) Elements of a theory for the mechanisms controlling abundance, diversity, and biogeochemical role of lytic bacterial viruses in aquatic systems. Limnol Oceanogr 45:1320 1328

Tsygankov AA, Borodin VB, Rao KK, Hall DO (1999) H(2) photoproduction by batch culture of Anabaena variabilis ATCC 
29413 and its mutant PK84 in a photobioreactor. Biotechnol Bioeng 64:709-715

van Bleijswijk J, Muyzer G (2004) genetic diversity of oxygenic phototrophs in microbial mats exposed to different levels of oil pollution. Ophelia 58:157-164

van Dam AA, Beveridge MCM, Azim ME, Verdegem MCJ (2002) The potential of fish production based on periphyton. Rev Fish Biol Fish 12:1-31

Vymazal J (1984) Short-term uptake of heavy metals by periphyton algae. Hydrobiologia 119:171-179

Vymazal J, Sladedek V, Stach J (2001) Biota participating in wastewater treatment in a horizontal flow constructed wetland. Water Sci Technol 44:211-214
Wang TC, Weissman JC, Ramesh G, Varadarajan R, Benemann JR (1998) Heavy metal binding and removal by Phormidium. Bull Environ Contam Toxicol 60:739-744

Ward DM, Ferris MJ, Nold SC, Bateson MM (1998) A natural view of microbial biodiversity within hot spring cyanobacterial mat communities. Microbiol Mol Biol Rev 62:1353-1370

Wiegand C, Pflugmacher S (2005) Ecotoxicological effects of selected cyanobacterial secondary metabolites: a short review. Toxicol Appl Pharmacol 203:201-218

Wimpenny J, Manz W, Szewzyk U (2000) Heterogeneity in biofilms. FEMS Microbiol Rev 24:661-671

Zehr JP, Turner PJ (2001) Nitrogen fixation: nitrogenase genes and gene expression. Methods Microbiol 30:271-285 